\title{
Updated landslide inventory of the area between the Furiano and Rosmarino creeks (Sicily, Italy)
}

\section{Federico Raspini, Andrea Ciampalini, Silvia Bianchini, Federica Bardi, Federico Di Traglia, Giuseppe Basile \& Sandro Moretti}

To cite this article: Federico Raspini, Andrea Ciampalini, Silvia Bianchini, Federica Bardi, Federico Di Traglia, Giuseppe Basile \& Sandro Moretti (2015): Updated landslide inventory of the area between the Furiano and Rosmarino creeks (Sicily, Italy), Journal of Maps, DOI: 10.1080/17445647.2015.1114975

To link to this article: http://dx.doi.org/10.1080/17445647.2015.1114975

+ View supplementary material

Published online: 25 Nov 2015.

Submit your article to this journal $\pi$

View related articles $₫$

View Crossmark data $\nearrow$ 


\title{
Updated landslide inventory of the area between the Furiano and Rosmarino creeks (Sicily, Italy)
}

\author{
Federico Raspini ${ }^{a}$, Andrea Ciampalini ${ }^{a}$, Silvia Bianchini ${ }^{a}$, Federica Bardi ${ }^{a}$, Federico Di Traglia ${ }^{a}$, Giuseppe Basile ${ }^{b}$ \\ and Sandro Moretti ${ }^{\mathrm{a}}$
}

${ }^{\mathrm{a} E}$ Earth Sciences Department, University of Firenze, Firenze, Italy; ${ }^{\mathrm{b}}$ Regional Department of Civil Protection (DRPC), Hydrogeological and Environmental Risks Service, Palermo, Italy

ABSTRACT

A 1:10,000 scale landslide inventory map has been prepared for the area between the Furiano and Rosmarino creeks, in the Nebrodi Mountains (north-eastern Sicily, Italy), a territory highly prone to slope failures, due to the local geological and geomorphological settings and intense rainfall. The landslide inventory database included within the Hydrogeological Setting Plan of the Sicily Region has been used as a starting point for this work. The updated inventory map has been compiled through a combination of conventional approaches (i.e. aerial photo-interpretation and field surveys) and new remote sensing techniques (ground deformation measurements obtained by interferometric analysis of satellite Synthetic Aperture Radar images). The new landslide inventory consists of 566 events, classified according to their typology and state of activity.
ARTICLE HISTORY

Received 4 February 2015

Revised 28 October 2015

Accepted 28 October 2015

\section{KEYWORDS}

Landslide inventory map; photo-interpretation; SARInterferometry; SqueeSAR ${ }^{\mathrm{TM}}$; San Fratello; Italy

\section{Introduction}

Landslide mapping activities rely on the representation of the spatial distribution, typology and state of activity of mass movements that have left detectable evidence on the investigated areas (Guzzetti, Cardinali, \& Reichenbach, 1996, 2012; Hervás, 2012; Malamud, Turcotte, Guzzetti, \& Reichenbach, 2004; van Westen, van Asch, \& Soeters, 2006).

The landslide inventory map (LIM) is the basic tool for any landslide hazard assessment at different scales and contributes to the improvement of risk management strategies for such natural hazards (Ciampalini et al., 2015; Guzzetti, Cardinali, Reichenbach, \& Carrara, 2000; Hansen, 1984; Pašek, 1975).

LIMs date back to the 1970s (Carrara \& Merenda, 1974), however since then many different mapping approaches exploiting both conventional (i.e. stereoscopic interpretation of aerial photography) (Ardizzone et al., 2012; Conforti, Muto, Rago, \& Critelli, 2014; Nichol, Shaker, \& Wong, 2006) and emerging techniques (mainly based on satellite remote sensing) (Mondini et al., 2011; Stumpf \& Kerle, 2011) have been implemented and used to document the occurrence of landslides in a certain study area.

Conventional methods for the production of LIM are based on the recognition of landslides and other geomorphological and hydrological features through the visual (stereoscopic) interpretation of aerial photographs, supported by field surveys for validation. These well-established methods, which have been utilized with standardized procedures for several decades, represent some of the most reliable tools, but they are resource intensive and time consuming (Brunsden, 1985; Cardinali et al., 2002). From the early 1990s, a number of modern techniques based on airborne and satellite remote sensing data have been used for the recognition of landslide features (Rengers, Soeters, \& van Westen, 1992). These new remote sensing technologies can support the compilation of LIMs, reducing the time for their production and saving economic resources required for timely updates.

Exhaustive review of the application of remote sensing techniques for landslide studies during the 1990s was undertaken by Mantovani, Soeters, and van Westen (1996). A further review was lately provided by Metternicht, Hurni, and Gogu (2005), who analysed the use of remote sensing data in landslide studies during the 1980s, 1990s and 2000s. More recently, Guzzetti et al. (2012), besides the outline of the principles for landslide mapping, reviewed both conventional methods and new technologies for the preparation of landslide maps.

A great variability of mapping procedures exists (Parise, 2001), depending on the exploited technique, on the ultimate purpose of the inventory as well as on the extent of the investigated area. Finally, the quality and the accuracy of the produced map may vary significantly with the scale of the map, the detail of the available information and the resources allocated to complete the work (Guzzetti et al., 2000; Mantovani et al., 1996). 
Among the many new technologies used in landslide investigations, the exploitation of images acquired by satellite Synthetic Aperture Radar (SAR) sensors is one of the most widespread. SAR-based techniques are capable of detecting and measuring displacements at specific points within large areas and to construct time series of deformation with millimetre accuracy. For this purpose, two main approaches can be adopted: (i) Differential SAR Interferometry (DInSAR), based on the comparison of the phase matrices of two SAR images acquired over the same target area (Fruneau, Achache, \& Delacourt, 1996; García-Davalillo, Herrera, Notti, Strozzi, \& Álvarez-Fernández, 2014; Massonnet \& Feigl, 1998; Massonnet, Feigl, Rossi, \& Adragna, 1994; Squarzoni, Delacourt, \& Allemand, 2003), and (ii) A-DInSAR (Advanced DInSAR), a family of techniques which relies on the processing of several (at least 15 , or more), co-registered, multi-temporal satellite SAR scenes.

Within the A-DInSAR family, the PSInSAR ${ }^{\mathrm{TM}}$ (Permanent Scatterer InSAR) technique (Ferretti, Prati, \& Rocca, 2000, 2001) and its evolution SqueeSAR ${ }^{\mathrm{TM}}$ (Ferretti et al., 2011) provide accurate information on the possible displacement of a network of radar targets (the Persistent and Distributed Scatterers, PS and DS) exhibiting a coherence level constant in time, such as man-made structures (e.g. buildings, roads and bridges) or natural features (e.g. rocky outcrops and bare soils).

Through the so-called 'radar interpretation' (Farina, Colombo, Fumagalli, Marks, \& Moretti, 2006) a 'geomorphological' meaning is assigned to the scattered point-wise ground displacement measurements derived from the interferometric analysis, by identifying, in areas characterized by deformation, terrain features and landforms related to slope instability. Examples of successful applications of A-DInSAR techniques to landslide analysis are presented by Hilley, Bürgmann, Ferretti, Novali, and Rocca, (2004), Herrera et al. (2011), Bianchini et al. (2013), Tofani, Raspini, Catani, and Casagli (2013), and Ciampalini et al. (2014).

The present study deals with landslide mapping in the area surrounding the San Fratello village (northern Sicily, Italy) between the Furiano creek on the west and the Rosmarino creek on the east. This area has a long history of landslide events. LIM activity for this area is aimed at integrating satellite-based ground deformation measurements with geomorphological analysis of landforms, that is, coupling a new remote sensing technique with a conventional approach.

\section{The study area}

The study area (Figure 1) extends for $160 \mathrm{~km}^{2}$ in the Messina province, along the Tyrrhenian coast of Sicily,
Italy. The river catchments included in the area are located along the northern-facing slope of the Nebrodi Mountains, a 70-km-long ridge with an ENE-WSW direction, within the southern Apennine chain. The Messina province is highly prone to landslides, mainly due to the steep topography, its geological nature and the occurrence, seasonally, of intense rainfall events (mostly falling in the period from October to February). Landslides, including shallow soil slides and debris flows, deep-seated rotational and translational slides, and complex and compound failures (according to the classification of Varnes, 1978) are abundant in the area, and caused primarily by rainfall (Goswami, Mitchell, \& Brocklehurst, 2011; Raspini, Moretti, \& Casagli, 2013). Between the end of 2009 and the beginning of 2010, intense and exceptional rainfall events affected the Nebrodi Mountains triggering several landslide events which caused extensive damage and casualties. One of the most affected zones was the area of the San Fratello village, a site with a long history of landslides (Bardi et al., 2014; Bianchini et al., 2014; Ciampalini et al., 2014).

\section{Geological and geomorphological framework}

From a geological point of view (Figure 1), the area is part of a collisional system, developed since the Late Cretaceous, as the result of the convergence between the European and African-Adriatic plates (Corrado, Aldega, Balestrieri, Maniscalco, \& Grasso, 2009). The area is characterized by the presence of two main structural domains: the Kabilian-Peloritan-Calabrian domain (located in the northeast sector of the study area), overthrust on the Apenninic-Maghrebian domain (outcropping in the southwest sector) (Lentini et al., 2000).

The Kabilian-Peloritan-Calabrian belt is composed of Paleozoic epimetamorphic rocks with related Mesozoic-Early Tertiary sedimentary covers (Giunta \& Nigro, 1999; Ogniben, 1960), overthrust by the Mandanici and Aspromonte units, which represent the Paleozoic metamorphic basement (Giunta \& Somma, 1996). These metamorphic rocks are overlain by the Capo D’Orlando Flysch (Oligocene-Burdigalian) (Bonardi et al., 1980).

The Apenninic-Maghrebian domain is represented by the Monte Soro unit, consisting of a $1500 \mathrm{~m}$ thick sequence of black and varicoloured shales with carbonate intercalations (Corrado et al., 2009). This unit is overlain by Cretaceous red and green shales with siltstones and fine-grained sandstones (Argille Scagliose Superiori).

The Early foredeep deposits are represented by the Antisicilide unit that is made of varicoloured clays of the oceanic domain (Lentini, Carbone, \& Grasso, 2000) and of the clastic deposits belonging to the 


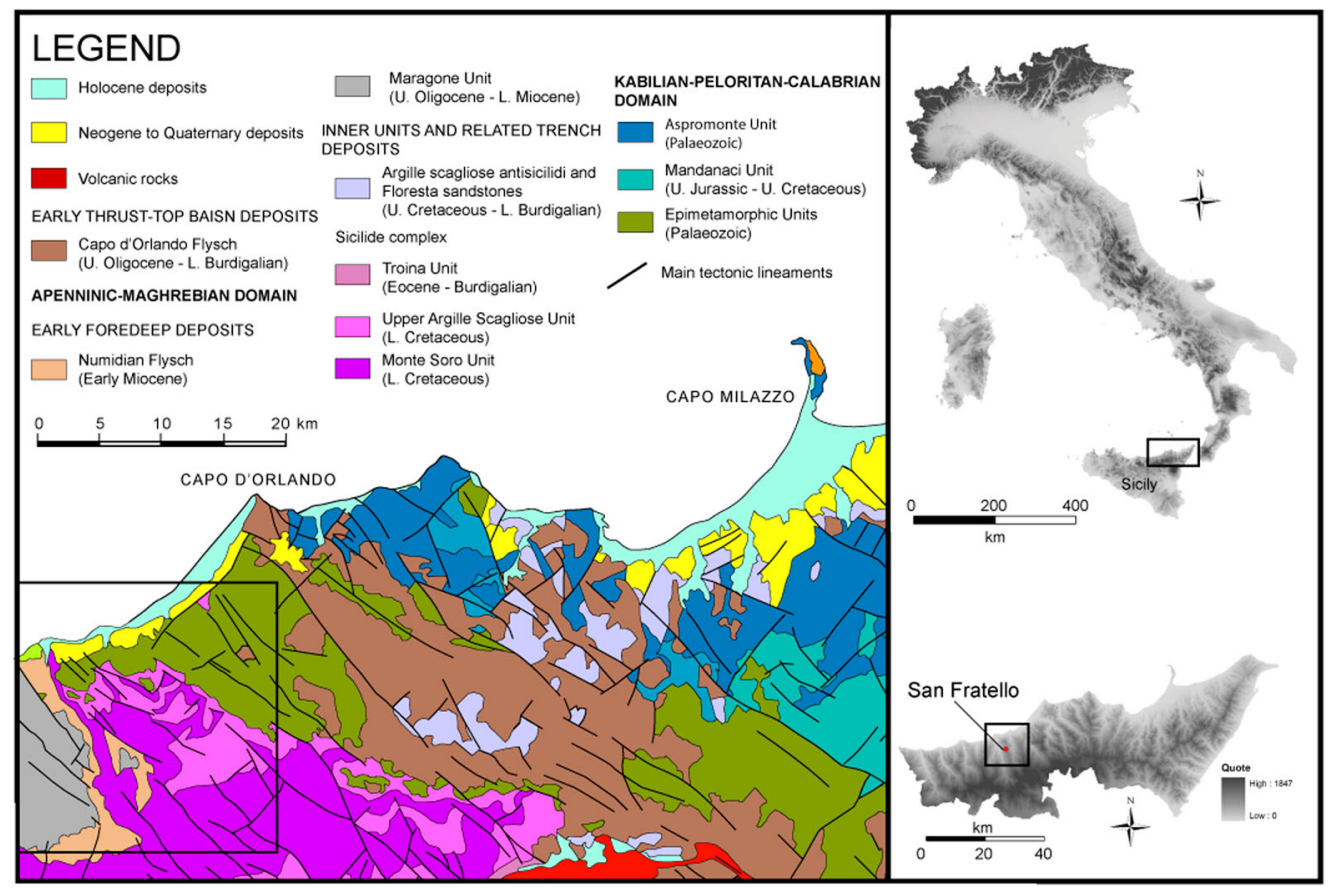

Figure 1. Schematic geological map (redrawn from Lentini et al., 2000) of the Nebrodi Mountains. The black square represents the study area.

Maragone unit and the Numidian flysch (Catalano, Di Stefano, Sulli, \& Vitale, 1996).

In the area, elevation ranges from sea level to about $1500 \mathrm{~m}$ and terrain gradient is in the range $0-80^{\circ}$. The catchments exhibit an ephemeral hydrological regime.

The geomorphology of the study area shows the typical features of the north-eastern Sicilian coastline. Steep slopes, narrow valleys and high relief energy are the main geomorphological features. The test site is strongly influenced by the geo-structural conditions and recent tectonic activity: slopes rise sharply from the coastal plain and are deeply cut by $\mathrm{N}-\mathrm{NW}$-directed creek valleys.

The morphometric characteristics of the river basins, represented by a river network having regular and parallel paths, are influenced by the short distance separating the watershed from the coast. River catchments have a reduced widening with a significant transport of solid materials. The presence of the so-called 'fiumare', straight, steep course, gravel-bed rivers draining mountain areas is typical of Mediterranean climate regions. Their flow varies seasonally and their regime is torrential with catastrophic transport of solid material following heavy rainfall, causing severe damage if flooding occurs close to populated centres.

\section{Methodology}

For the study area, we prepared a detailed LIM at 1:10,000 scale. The final purpose of this study was the updating and improvement of pre-existing landslide inventory maps by mapping the phenomena not previously recorded and including information on typology and state of activity of each identified phenomenon.

The pre-existing LIM of the study area is the Piano di Assetto Idrogeologico, Hydro-geological Setting Plan (PAI) (Adb Regione Sicilia, 2012), which is dated up to 2012 and includes landslides classified with respect to typology and state of activity (active, dormant, inactive - including relict and abandoned phenomena - and stabilized), according to a simplified version of Cruden and Varnes (1996) classification (Figure 2).

The pre-existing LIM, between the Furiano and Rosmarino creeks, consists of 395 events: 10 (2\%) rockfalls or topples, 36 (10\%) rapid flows, 46 (12\%) slides, 152 (38\%) complex landslides, 17 (4\%) flows, 40 (10\%) superficial instability events, 57 (14\%) creep or solifluctions and 37 (10\%) rapid erosion. In total, the mapped phenomena within the pre-existing inventory map cover an area of $28.8 \mathrm{~km}^{2}$.

The updating of the PAI has been performed through a combination of: (i) radar interpretation of four different available SAR datasets, processed with the SqueeSAR ${ }^{\mathrm{TM}}$ approach; (ii) photo-interpretation of 1:33,000 scale aerial photographs flown in 1954, 1955 and 2005; and (iii) field surveys carried out for the final validation.

Radar- and photo-interpretation procedures combined with a field validation allowed the detection, mapping and characterization of landslides. In particular, landslide detection (recognition of topographic features related to surface movements) and classification (identification of the typology of landslides according to standardized classifications) were mainly based on 


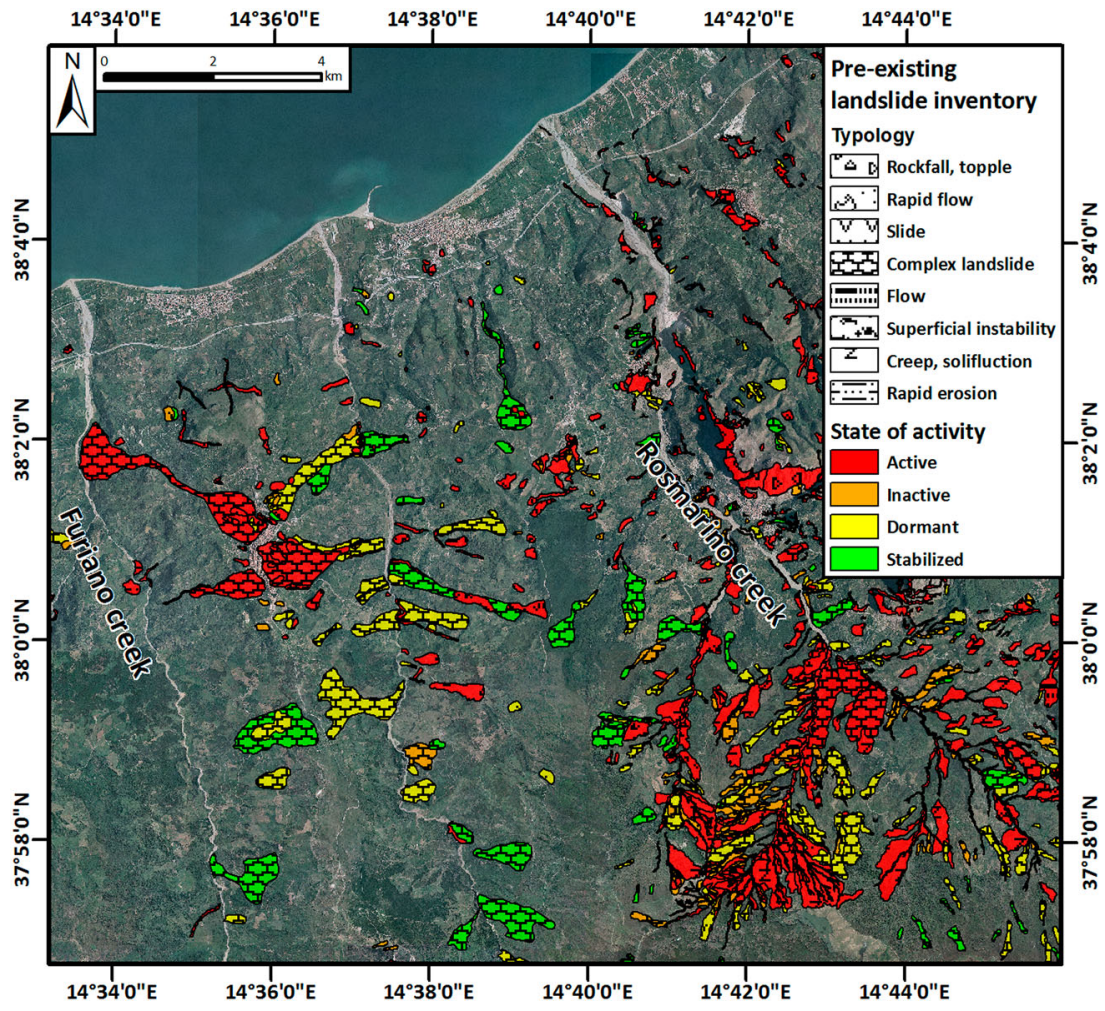

Figure 2. Pre-existing landslide inventory map (PAI - Piano di Assetto Idrogeologico) for the study area.

visual interpretation of aerial photographs, whilst mapping and assessment of the state of activity of landslides benefited from SAR-based information.

Recognition of landslides and related geomorphological and hydrological features through the stereoscopic analysis of aerial photographs is a complex operation that requires training, experience, a systematic methodology and well-defined interpretation criteria. Photo-interpretation is aimed at detecting and classifying geological objects and geomorphological forms, by analysing different characteristics that can be identified or inferred from the photographs (i.e. shape, size, colour, tone, mottling, texture, and pattern of objects and site topography). The final purpose of photo-interpretation is the detection of discernible features related to mass movements.

Photo-interpretation has been supported by outcomes of the SqueeSARTM analysis applied to four SAR datasets (Table 1). The SqueeSAR ${ }^{\mathrm{TM}}$ approach is the most consolidated technique to accurately map, monitor and analyse ground motion in natural terrain (Ferretti et al., 2011).
Despite this effectiveness, some limitations have to be considered when dealing with SAR-based information: firstly, the low sensitivity to detect movements with a predominant horizontal $\mathrm{N}-\mathrm{S}$ direction, whilst in contrast zenithal or E-W components can be successfully observed and evaluated. In the present work, this problem is reduced as the study area is characterized by $\mathrm{N}-\mathrm{S}$ oriented ridges and $\mathrm{E}-\mathrm{W}$ facing slopes.

Moreover, it is known that SAR-interferometry techniques can only be exploited to map slow-moving landslides that are classified according to Cruden and Varnes (1996), as extremely slow (velocity $<16 \mathrm{~mm} /$ yr) and very slow $(16 \mathrm{~mm} / \mathrm{yr}<$ velocity $<1,6 \mathrm{~m} / \mathrm{yr})$, due to the intrinsic characteristics of the acquisition systems (i.e. signal wavelength and revisit time). Therefore, the phenomena classified within the PAI as 'rapid erosion' and 'rapid flow' cannot be detected due to their rapid and intermittent kinematics, and they are not included in the statistical analysis.

Finally, specific field checks and surveys were carried out in November 2012 and January 2013, in order to validate Persistent Scatterer Interferometry

Table 1. Characteristics (employed band, acquisition geometry, revisiting time, temporal interval, number of scenes and PS density) of the datasets used for the update of the LIM. CSA: Canadian Space Agency; ASI (Italian Space Agency).

\begin{tabular}{|c|c|c|c|c|c|c|c|}
\hline Satellite & Agency & Band & Geometry & Revisiting time (day) & $\begin{array}{l}\text { Temporal range } \\
(\mathrm{dd} / \mathrm{mm} / \mathrm{yy})\end{array}$ & No. of scenes & PS $\left(\mathrm{km}^{2}\right)$ \\
\hline RADARSAT-1 & CSA & C & Ascending & 24 & $30 / 12 / 05-04 / 09 / 09$ & 46 & 112.73 \\
\hline RADARSAT- 1 & CSA & $\mathrm{C}$ & Descending & 24 & $31 / 01 / 06-06 / 10 / 09$ & 47 & 86.86 \\
\hline COSMO-SkyMed (CSK) & ASI & $x$ & Ascending & 4 & 01/05/11-03/05/12 & 26 & 219.85 \\
\hline COSMO-SkyMed (CSK) & ASI & $x$ & Descending & 4 & $16 / 05 / 11-02 / 05 / 12$ & 32 & 400.62 \\
\hline
\end{tabular}




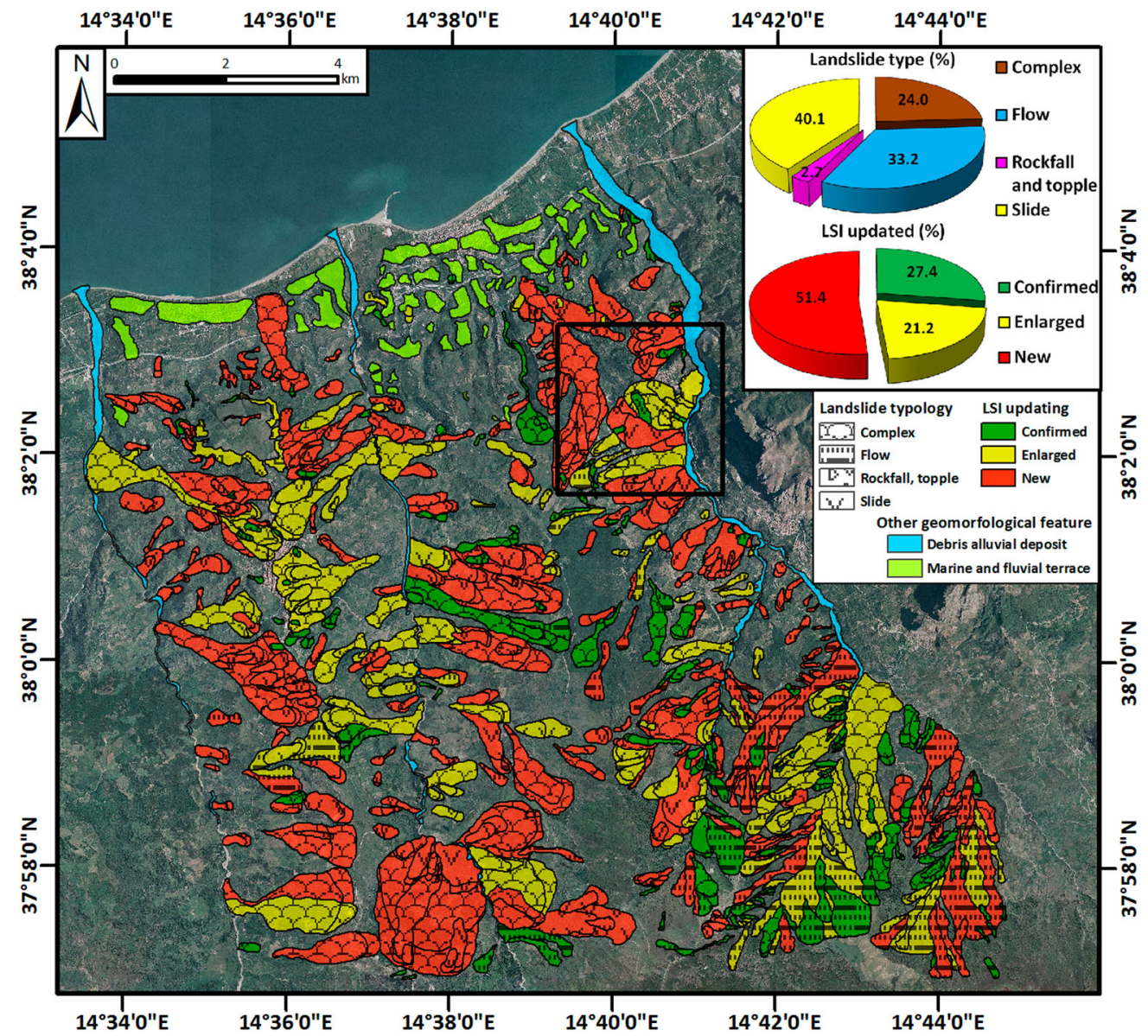

Figure 3. Updated LIM. In the inset, the close-up area of Militello Rosmarino of Figures 4, 5 and Figure 6 is shown.

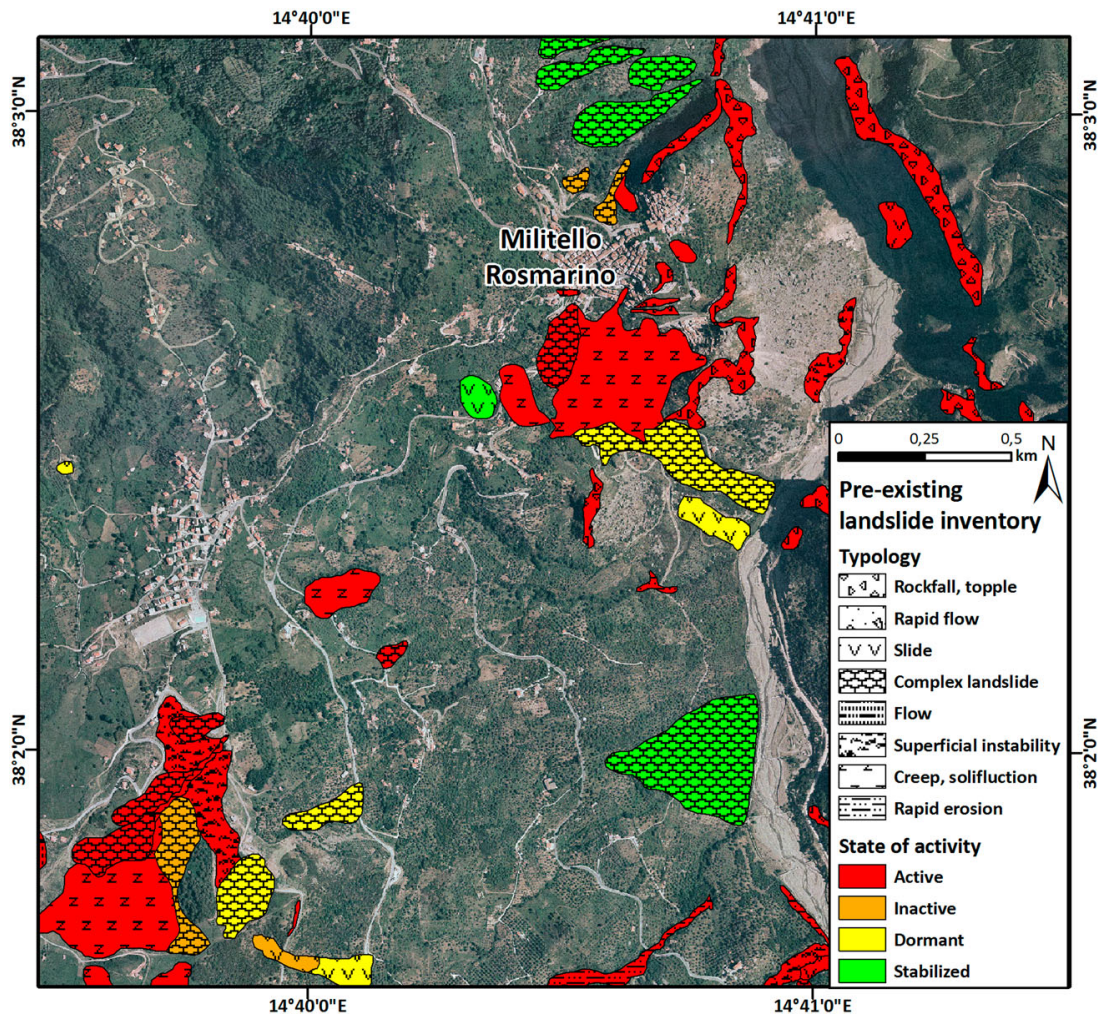

Figure 4. PAI in the area south of Militello Rosmarino. 
(PSI)-based analysis performed at a desk, prior to insitu investigations. Field surveys focused on both ground and building crack identification. Field checks and observations also allowed the recognition of typical indicators of landslide movement (e.g. trenches, scarps, counterscarps and cracks).

The applied procedure allows the updating of the pre-existing LIM by identifying new landslides, modifying the boundaries of pre-existing ones and assessing the typology and the state of activity following the Cruden and Varnes (1996) classification. The simultaneous use of two different interferometric datasets, acquired in different periods, is very useful to evaluate the state of activity of slow-moving landslides. The assessment of the state of activity is based on the comparison between the mean velocity detected using of the older available datasets (RADARSAT-1 2006-2009) and that obtained using more recent ones (CSK 20112012). In order to update the landslide state of activity, a simplified version of the terminology proposed by Cruden and Varnes (1996) is used and it consists of three classes: active (PS velocity higher than $1.5 \mathrm{~mm} /$ yr in both RADARSAT and CSK datasets), inactive
(PS velocity lower than $1.5 \mathrm{~mm} / \mathrm{yr}$ in both RADARSAT and CSK datasets) and not determined (lack of interferometric data).

\section{Results and discussion}

LIM has been performed at basin scale including recognition, mapping, classification and assessment of state of activity of each identified phenomenon. The updated inventory map of Figure 3 shows: (i) the distribution, typology and state of activity of the landslides and (ii) information on fluvial processes and other geomorphological features (i.e. fluvial and marine terraces).

Landslide classification was based on the prevalent type of movement (Cruden \& Varnes, 1996), the estimated depth and the relative age. Landslide types were determined by considering the local morphological characteristics, the appearance on the aerial photographs, and the lithological and structural setting. Landslides are represented by rockfalls and topples, flows, slides and complex landslides.

Rockfalls and topples are located predominantly in the northern part of the area, where steep slopes and

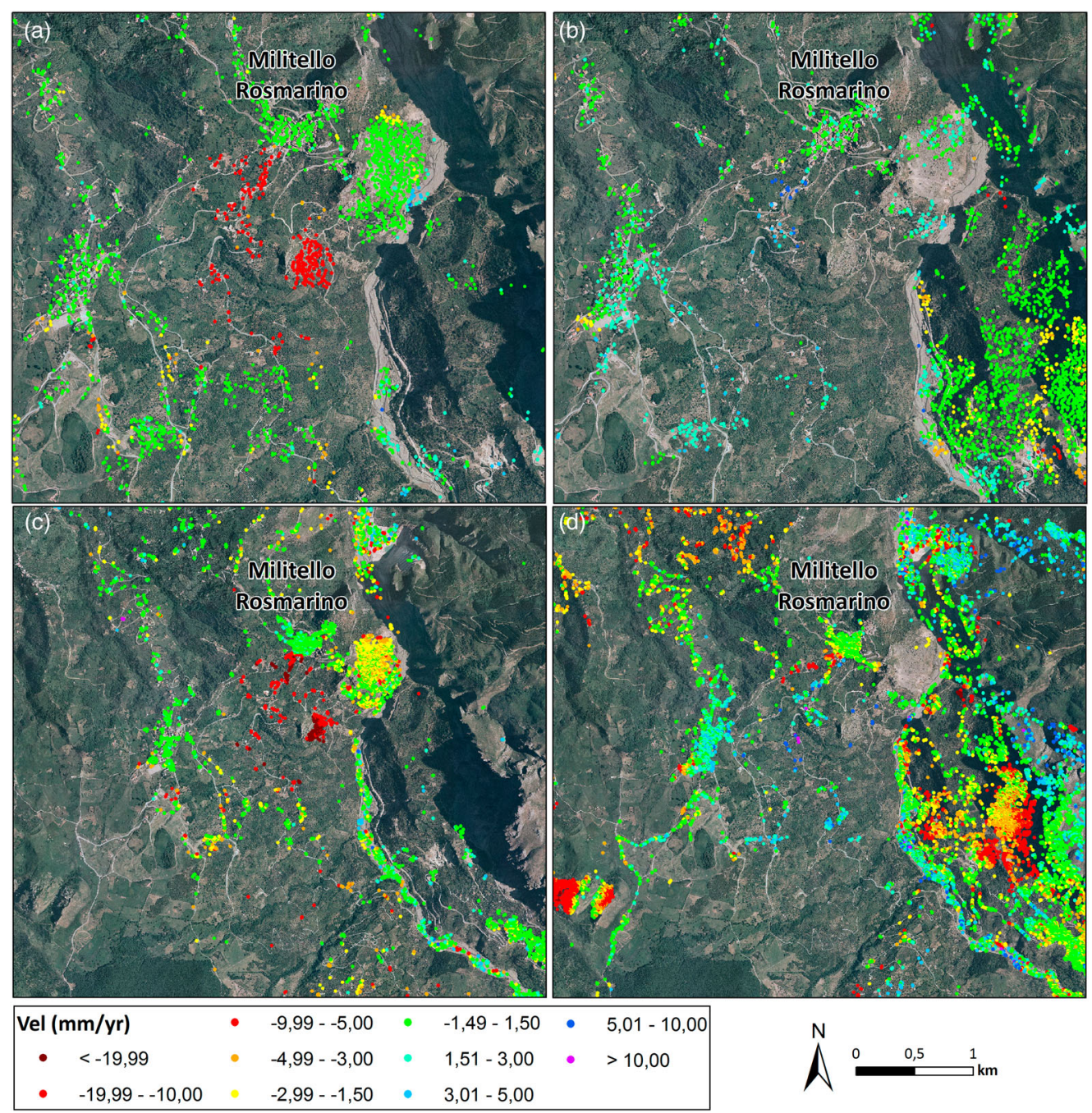

Figure 5. PSI results for the Militello Rosmarino area: (a) RADARSAT-1 ascending; (b) RADARSAT-1 descending; (c) CSK ascending; (d) CSK descending. 
more resistant rocks are present (i.e. Mesozoic-Early Tertiary massive limestone belonging to the Kabilian-Peloritan-Calabrian belt). The source areas of the rockfalls and topples are the result of a single event or of multiple events that occurred at different times, and are likely associated with the presence of faults, joints and multiple cleavage systems.

Flows are superficial phenomena more common in the south-eastern part of the area where the formation of the Argille Scagliose (scaly clay) crops out extensively. Moreover, flows have been mapped where debris is abundant along the slopes, such as in tectonized areas, in landslide deposits and along scree slopes.

Small slides are mostly shallow translational movements located inside other landslides and along undisturbed slopes. Larger slides are deep-seated, rotational and translational slides. Deep-seated landslides involve large volumes of material and affect the local morphology and geological structures.

Complex landslides are characterized by a combination of two or more types of movement with a spatial and temporal predominance of one of them.

Where possible, slides and complex landslides were mapped separating the depletion area (with a concave profile) and the accumulation zone (characterized by an irregular or convex profile representing the deposit). In the case of flow-type landslides and rockfalls, the mapped perimeter includes both source area and run-out/accumulation zone.

The updated LIM consists of 566 events: 15 (2.7\%) rockfalls and topples, $136(24.0 \%)$ complex landslides, 188 (33.2\%) flows and 227 (40.1\%) slides. In total, the mapped phenomena of the updated inventory map cover an area of $74.1 \mathrm{~km}^{2}$. (Main Map)

Three classes have been adopted for a second-level classification of the landslide events included in the updated inventory map: confirmed (when the perimeter of the landslide mapped within the PAI was confirmed as it is), enlarged (when the boundaries of the phenomenon were increased) and new (when a new phenomenon has been identified and mapped) (Figure 3).

Summarizing, within the whole updated LIM, 120 events $(21.2 \%)$ of the pre-existing database have been enlarged, 155 events (27.4\%) have been confirmed, while 291 (51.4\%) new phenomena have been mapped.

A representative example of the performed activity and of the type of landslides mapped in the whole area is reported below for the area of Militello Rosmarino, located along the left bank of the Rosmarino river. Figure 4 shows the PAI, which records few instability events, among which some complex landslides, creep events and small rockfall areas.

An overview of the PSI results for RADARSAT-1 and CSK datasets is shown in Figure 5. The PSI results

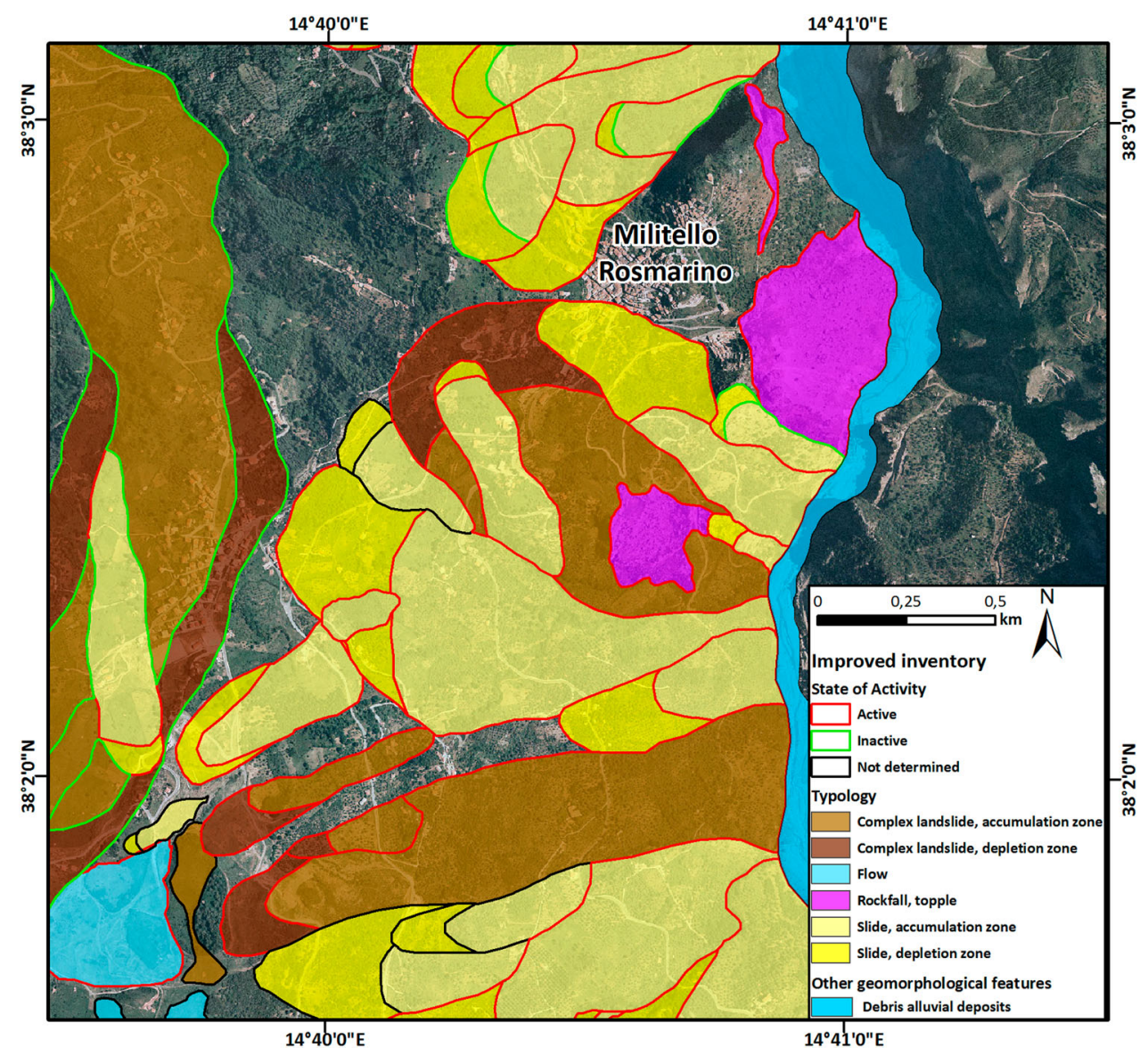

Figure 6. Updated LIM in the area south of Militello Rosmarino. 
highlight ground displacements in both old (20062009) and recent (2011-2012) scenarios. In particular, available datasets identify a large sector, south of the Militello Rosmarino village, characterized by a displacement with an average velocity ranging from -6 to $-15 \mathrm{~mm} / \mathrm{yr}$ with peaks of $-20 \mathrm{~mm} / \mathrm{yr}$ in the RADARSAT-1 dataset, and from -10 to $-25 \mathrm{~mm} / \mathrm{yr}$ with peaks of $-34 \mathrm{~mm} / \mathrm{yr}$ in the CSK dataset.

Radar- and photo-interpretation, analysis of Digital Elevation Model (DEM) and derived maps (i.e. aspect and slope) and field surveys allow detection and mapping of a large active complex landslide system affecting the area (Figure 6). It is worth highlighting the occurrence of two large deposits of rocky blocks at the foot of steep cliffs.

\section{Conclusions}

A 10,000 scale LIM has been prepared for the area between the Furiano and Rosmarino creeks, on the northern-facing slope of the Nebrodi Mountains (Sicily, Italy), an area chronically affected by landslides.

The starting point of this work was the pre-existing landslide database included within the PAI of the Sicily Region. The updating of the PAI database has been performed through a combination of radar interpretation of InSAR displacement measurements acquired in different periods (2006-2009, RADARSAT-1 scenes and 2011-2012, COSMO-SkyMed images), photointerpretation of $1: 33,000$ scale aerial photographs and field surveys carried out for the final validation in November 2012 and January 2013.

Integration of InSAR datasets and stereoscopic analysis of aerial photographs were used to better define the landslide boundaries, to highlight the areas affected by ground displacements located outside the pre-existing landslide boundaries and to detect ground deformation phenomena not previously mapped.

The updated landslide inventory consists of 566 events, classified according to their typology and state of activity. The obtained results show an increase in the mapped phenomena: 120 events (21.2\%) of the pre-existing database have been enlarged, 155 events (27.4\%) have been confirmed, while 291 (51.4\%) new phenomena mapped.

Output of the presented work can be used by local administrations, decision makers and Civil Protection authorities to prepare landslide susceptibility maps, hazard models and risk mitigation plans.

\section{Software}

Esri ArcGIS 9.3 was used to digitize the landslide and geomorphological information collected by aerial photo- interpretation. The cartographic rendering and layout have been performed in Adobe Illustrator CS4.

\section{Acknowledgements}

The authors gratefully acknowledge Telerilevamento Europa - T.R.E. (Italy) for having processed SAR data. Further thanks go to the editors (Félix González-Peñaloza and Mike Smith) and to the four reviewers (Juan Carlos García López-Davalillo, Federica Ferrari, Javier Hervas and Mike Shand) for their valuable comments.

\section{Disclosure statement}

No potential conflict of interest was reported by the authors.

\section{Funding}

The research leading to these results has been carried out in the framework of the DORIS project (http://www.dorisproject.eu/) [grant agreement number 242212] and LAMPRE project (http://www.lampre-project.eu/) [Grant Agreement No. 312384] projects, both of them promoted and funded under the Seventh Framework Program of the European Commission.

\section{References}

Autorità di Bacino (AdB) Regione Sicilia. (2012). PAI Piano Stralcio di Bacino per l'Assetto Idrogeologico Retrieved September 10, 2014, from http://www.sitr. regione.sicilia.it/pai

Ardizzone, F., Basile, G., Cardinali, M., Casagli, N., Del Conte, S., Del Ventisette, C.... Terranova, O. (2012). Landslide inventory map for the Briga and the Giampilieri catchments, NE Sicily, Italy. Journal of Maps, 8(2), 176-180.

Bardi, F., Frodella, W., Ciampalini, A., Bianchini, S., Del Ventisette, C., Gigli, G., ... Casagli, N. (2014). Integration between ground based and satellite SAR data in landslide mapping: The San Fratello case study. Geomorphology, 223, 45-60.

Bianchini, S., Ciampalini, A., Raspini, F., Bardi, F., Di Traglia, F., Moretti, S., \& Casagli, N. (2014). Multi-temporal evaluation of landslide movements and impacts on buildings in San Fratello (Italy) by means of C-band and X-band PSI data. Pure and Applied Geophysics, 17(6), 1-23.

Bianchini, S., Herrera, G., Mateos, R. M., Notti, D., Garcia, I., Mora, O., \& Moretti, S. (2013). Landslide activity maps generation by means of Persistent Scatterer Interferometry. Remote Sensing, 5(12), 6198-6222.

Bonardi, G., Giunta, G., Perrone, V., Russo, M., Zuppetta, A., \& Ciampo, G. (1980). Osservazioni sull' evoluzione dell'Arco Calabro-Peloritano nel Miocene inferiore: la Formazione di Stilo-Capo d'Orlando. Bollettino della Società Geologica Italiana, 99, 365-393.

Brunsden, D. (1985). Landslide types, mechanisms, recognition, identification. In C. S. Morgan (Ed.), Landslides in the South Wales coalfield, proceedings symposium (pp. 19-28). Trefforest: The Polytechnic of Wales.

Cardinali, M., Reichenbach, P., Guzzetti, F., Ardizzone, F., Antonini, G., Galli, M., ... Salvati, P. (2002). A geomorphological approach to estimate landslide hazard and risk in 
urban and rural areas in Umbria, central Italy. Natural Hazards and Earth System Sciences, 2(1-2), 57-72.

Carrara, A., \& Merenda, L. (1974). Metodologia per un censimento degli eventi franosi in Calabria. Geologia Applicata e Idrogeologia, 10, 237-255.

Catalano, R., Di Stefano, P., Sulli, A., \& Vitale, E. P. (1996). Paleogeography and structure of the Central Mediterranean: Sicily and its offshore area. Tectonophysics, 260, 291-323.

Ciampalini, A., Bardi, F., Bianchini, S., Frodella, W., Del Ventisette, C., Moretti, S., \& Casagli, N. (2014). Analysis of building deformation in landslide area using multisensor PSInSAR ${ }^{\mathrm{TM}}$ technique. International Journal of Applied Earth Observation and Geoinformation, 33, 166-180.

Ciampalini, A., Raspini, F., Bianchini, S., Fordella, W., Bardi, F., Lagomarsino, D., ... Basile, G. (2015). Remote sensing as tool for development of landslide databases: The case of the Messina Province (Italy) geodatabase. Geomorphology. doi:10.1016/j.geomorph.2015.01.029.

Conforti, M., Muto, F., Rago, V., \& Critelli, S. (2014). Landslide inventory map of north-eastern Calabria (South Italy). Journal of Maps, 10(1), 90-102.

Corrado, S., Aldega, L., Balestrieri, M. L., Maniscalco, R., \& Grasso, M. (2009). Structural evolution of the sedimentary accretionary wedge of the alpine system in Eastern Sicily: Thermal and thermochronological constraints. Geological Society of America Bulletin, 121(11-12), 1475-1490.

Cruden, D. M., \& Varnes, D. J. (1996). Landslides: Investigation and mitigation. Chapter 3-Landslide types and processes. Transportation Research Board Special Report, Special Report number (247), 36-75.

Farina, P., Colombo, D., Fumagalli, A., Marks, F., \& Moretti, S. (2006). Permanent scatterers for landslide investigations: Outcomes from the ESA-SLAM project. Engineering Geology, 88, 200-217.

Ferretti, A., Fumagalli, A., Novali, F., Prati, C., Rocca, F., \& Rucci, A. (2011). A new algorithm for processing interferometric data-stacks: SqueeSAR ${ }^{\mathrm{TM}}$. IEEE Transactions on Geoscience and Remote Sensing, (99), 1-11.

Ferretti, A., Prati, C., \& Rocca, F. (2000). Nonlinear subsidence rate estimation using permanent scatterers in differential SAR interferometry. IEEE Transactions on Geoscience and Remote Sensing. 38(5), 2202-2212.

Ferretti, A., Prati, C., \& Rocca, F. (2001). Permanent scatterers InSAR interferometry. IEEE Transactions on Geoscience and Remote Sensing, 39, 8-20.

Fruneau, B., Achache, J., \& Delacourt, C. (1996). Observation and modelling of the Saint-Etienne-de-Tinée landslide using SAR interferometry. Tectonophysics, 265(3), 181-190.

García-Davalillo, J. C., Herrera, G., Notti, D., Strozzi, T., \& Álvarez-Fernández, I. (2014). DInSAR analysis of ALOS PALSAR images for the assessment of very slow landslides: The Tena Valley case study. Landslides, 11(2), 225-246.

Giunta, G., \& Nigro, F. (1999). Tectono-sedimentary constraints to the Oligocene-to-Miocene evolution of the Peloritani thrust belt (NE Sicily). Tectonophysics, 315, 287-299.

Giunta, G., \& Somma, R. (1996). Nuove osservazioni sulla struttura dell'Unità di Alì (Mt. Peloritani, Sicilia NE). Bollettino della Società Geologica Italiana, 115, 489-500.

Goswami, R., Mitchell, N. C., \& Brocklehurst, S. H. (2011). Distribution and causes of landslides in the eastern Peloritani of NE Sicily and western Aspromonte of SW Calabria, Italy. Geomorphology, 132, 111-122.

Guzzetti, F., Cardinali, M., \& Reichenbach, P. (1996). The influence of structural setting and lithology on landslide type and pattern. Environmental and Engineering Geoscience, 2(4), 531-555.

Guzzetti, F., Cardinali, M., Reichenbach, P., \& Carrara, A. (2000). Comparing landslide maps: A case study in the upper Tiber River Basin, Central Italy. Environmental Management, 25(3), 247-363.

Guzzetti, F., Mondini, A. C., Cardinali, M., Fiorucci, F., Santangelo, M., \& Chang, K-T. (2012). Landslide inventory maps: New tools for an old problem. Earth-Science Reviews, 112, 42-66.

Hansen, A. (1984). Strategies for classification of landslides. In D. Brunsden \& D. B. Prior (Eds.), Slope instability (pp. 523-602) New York, NY: Wiley

Herrera, G., Notti, D., García-Davalillo, J. C., Mora, O., Cooksley, G., Sánchez, M., ... Crosetto, M. (2011). Analysis with $\mathrm{C}$-and X-band satellite SAR data of the Portalet landslide area. Landslides, 8(2), 195-206.

Hervás, J. (2012). Landslide inventory. In P. T. Bobrowky (Ed.), Encyclopedia of natural hazards (pp. 610-611). Heidelberg: Springer.

Hilley, G. E., Bürgmann, R., Ferretti, A., Novali, F., \& Rocca, F. (2004). Dynamics of slow-moving landslides from permanent scatterer analysis. Science, 304(5679), 1952-1955.

Lentini, F., Carbone, S., \& Grasso, M. (2000). Carta geologica della Provincia di Messina. Scale 1:50.000, 3 sheets. Nota illustrativa a cura di Lentini F., Catalano S. \& Carbone S., 70 pp., S.EL.CA, Firenze.

Malamud, B. D., Turcotte, D. L., Guzzetti, F., \& Reichenbach, P. (2004). Landslide inventories and their statistical properties. Earth Surface Processes and Landforms, 29(6), 687-711.

Mantovani, F., Soeters, R., \& van Westen, C. (1996). Remote sensing techniques for landslide studies and hazard zonation in Europe. Geomorphology, 15, 213-225.

Massonnet, D., Feigl, K., Rossi, M., \& Adragna, F. (1994). Radar interferometric mapping of deformation in the year after the Landers earthquake. Nature, 369(6477), 227-230.

Massonnet, D., \& Feigl, K. L. (1998). Radar interferometry and its application to changes in the Earth's surface. Reviews of Geophysics-Richmond Virginia Then Washington, 36, 441-500.

Metternicht, G., Hurni, L., \& Gogu, R. (2005). Remote sensing of landslides: An analysis of the potential contribution to geo-spatial systems for hazard assessment in mountainous environments. Remote Sensing of Environment, 98(2), 284-303.

Mondini, A. C., Guzzetti, F., Reichenbach, P., Rossi, M., Cardinali, M., \& Ardizzone, F. (2011). Semi-automatic recognition and mapping of rainfall induced shallow landslides using satellite optical images. Remote Sensing of Environment, 115, 1743-1757.

Nichol, E. J., Shaker, A., \& Wong, M.-S. (2006). Application of high-resolution stereo satellite images to detailed landslide hazard assessment. Geomorphology, 76, 68-75.

Ogniben, L. (1960). Nota illustrativa dello schema geologico della Sicilia nord-orientale. Rivista Mineraria Siciliana, 64-65, 183-222.

Parise, M. (2001). Landslide mapping techniques and their use in the assessment of the landslide hazard. Physics and Chemistry of the Earth, 26(9), 697-703.

Pašek, J. (1975). Landslide inventory. International Association Engineering Geologist Bulletin, 12, 73-74.

Raspini, F., Moretti, S., \& Casagli, N. (2013). Landslide mapping using SqueeSAR Data: Giampilieri (Italy) Case study. 
In Landslide science and practice (pp. 147-154). Berlin Heidelberg: Springer.

Rengers, N., Soeters, R., \& van Westen, C. J. (1992). Remote sensing and GIS applied to mountain hazard mapping. Episodes, 15(1), 36-45.

Squarzoni, C., Delacourt, C., \& Allemand, P. (2003). Nine years of spatial and temporal evolution of the La Valette landslide observed by SAR interferometry. Engineering Geology, 68(1), 53-66.

Stumpf, A., \& Kerle, N. (2011). Object-oriented mapping of landslides using Random Forests. Remote Sensing of Environment, 115(10), 2564-2577.
Tofani, V., Raspini, F., Catani, F., \& Casagli, N. (2013). Persistent Scatterer Interferometry (PSI) technique for landslide characterization and monitoring. Remote Sensing, 5(3), 1045-1065.

Varnes, D. J. (1978). Slope movement types and processes. In R. L. Schuster \& R. J. Krizek (Eds.), Landslides: Analysis and control (pp. 11-33). Transportation research board special report, 176, 1-81.

van Westen, C. J., van Asch, T. W. J., \& Soeters, R. (2006). Landslide hazard and risk zonation - Why is it still so difficult? Bulletin of Engineering Geology and the Environment, 65, 167-184. 